\title{
Primary hydatid cyst in the medial thigh
}

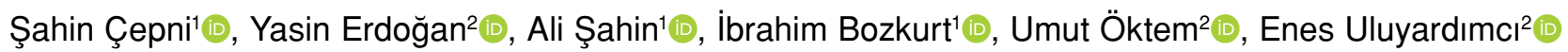 \\ 'Department of Orthopedics and Traumatology, Ankara City Hospital, Ankara, Turkey \\ ${ }^{2}$ Department of Orthopedics and Traumatology, Ankara Yıldırım Beyazıt University, Faculty of Medicine, Ankara, Turkey
}

The human body is an intermediate host for Echinococcus granulosus (E. granulosus), which is the most common cause of hydatid disease. This type of parasite mostly affects the liver and lungs. ${ }^{[1]}$ Hydatid cysts are endemic in countries heavily engaged in animal husbandry, particularly in intensive sheep farming areas, and is an endemic disease in the Mediterranean, the Middle East, the Far East and South America ${ }^{[1]}$ Primary involvement of subcutaneous tissue is extremely rare, with localization in muscle and subcutaneous tissue reported as 0.5 to $4.7 \%{ }^{[2]}$ In this article, we present a case of a large soft tissue cyst showing subcutaneous localization in the medial thigh, together with the clinical findings, treatment, and outcomes.

\section{CASE REPORT}

A 51-year-old female patient presented to our outpatient clinic with the complaint of swelling on the upper medial right thigh. Her medical history revealed

Received: January 13, 2022

Accepted: January 16, 2022

Published online: February 10, 2022

Correspondence: Enes Uluyardımcı, MD. Yıldırım Beyazı† Üniversitesi Tıp Fakültesi Ortopedi ve Travmatoloji Anabilim Dalı, 06800 Çankaya, Ankara, Türkiye.

E-mail: enesuluyardmc7@hotmail.com

Doi: $10.52312 /$ jdrscr.2022.59

Citation: Çepni Ş, Erdoğan Y, Şahin A, Bozkurt I, Öktem U, Uluyardımcı E. Primary hydatid cyst in the medial thigh. Jt Dis Relat Surg Case Rep 2022;1(2):71-74.

C2022 All right reserved by the Turkish Joint Diseases Foundation

This is an open access article under the terms of the Creative Commons Attribution-NonCommercial License, which permits use, distribution and reproduction in any medium, provided the original work is properly cited and is not used for commercial purposes (http://creativecommons.org/licenses/by-nc/4.0/).

https://www.casereportsjointdrs.org

\section{ABSTRACT}

The human body is an intermediate host for Echinococcus granulosus (E. granulosus), which is the most common cause of hydatid disease. This type of parasite mostly affects the liver and lungs. Primary involvement of subcutaneous tissue is extremely rare. A 51-year-old female presented with the complaint of swelling on the upper medial right thigh. On ultrasonography, a cystic lesion with thick walls, approximately $50 \times 90 \mathrm{~mm}$ in size, was observed approximately $8.5 \mathrm{~mm}$ from the skin within the muscle planes in the medial section of the right thigh. Entry was made over the mass from the medial thigh and the mass was totally excised. The histopathological diagnosis was confirmed as hydatid cyst. No pathological findings consistent with hydatid cyst were determined in the liver or other systems. In particular, in areas of endemic hydatid disease, it must be kept in mind that these types of atypical localizations, other than in the liver and lungs, can be encountered in many different anatomic regions.

Keywords: Hydatid cyst, muscular hydatidosis, soft tissue, thigh hydatid cyst.

that the patient was engaged in farming with close contact with sheep and dogs. Swelling was present for approximately two years and was progressively growing, but there was no other complaint such as pain. On physical examination, an immobile mass was identified with subcutaneous localization in the medial of the right thigh, approximately $12 \times 15 \mathrm{~cm}$ in size, which was painless, of soft texture, fluctuating, and extending as far as the proximal groin. The general condition of the patient was good, with no additional systemic problems such as fever, weight loss, or history of disease or trauma.

Other than soft tissue swelling in the medial femur, no findings were seen on direct radiographs (Figure 1). The laboratory test results of full blood count erythrocyte sedimentation rate, urine and blood biochemical parameters were within normal 


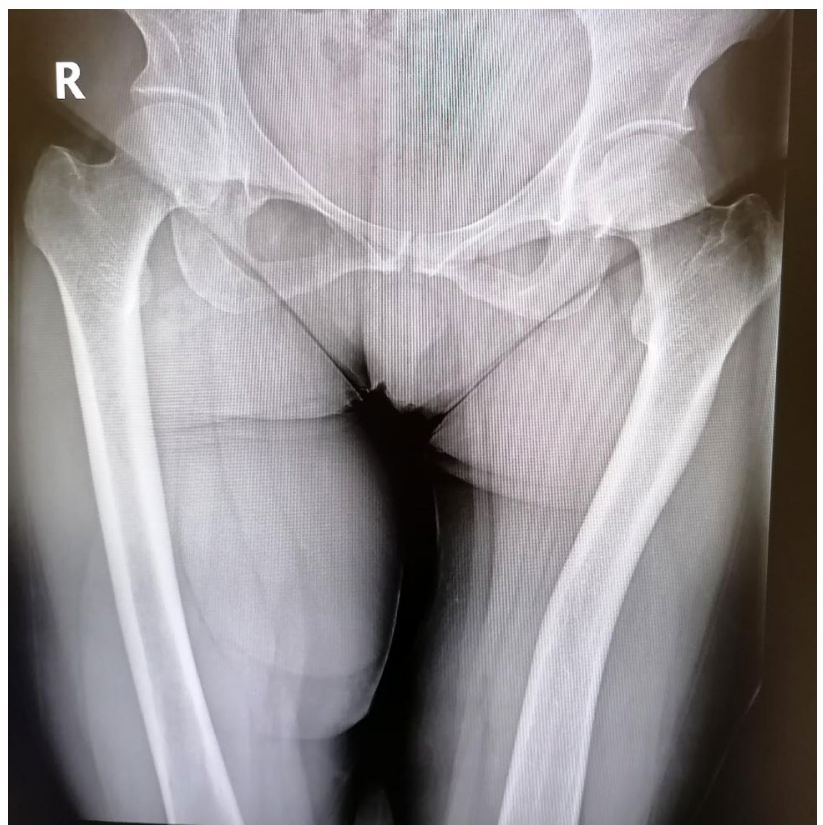

Figure 1. Soft tissue swelling on the right thigh seen on direct pelvis radiography. limits. On ultrasonography, a cystic lesion with thick walls, approximately $50 \times 90 \mathrm{~mm}$ in size, was observed approximately $8.5 \mathrm{~mm}$ from the skin within the muscle planes in the medial section of the right thigh. The lesion had dense content not showing bleeding on color Doppler ultrasound. On magnetic resonance imaging (MRI), a cystic mass lesion was located within the medial adductor muscle group of the right thigh, starting subcutaneously and extending to the proximal inguinal region (Figure 2). No pathological findings were observed on the pulmonary radiograph.

Under epidural anesthesia, entry was made over the mass from the medial thigh and the mass was totally excised (Figure 3). The histopathological diagnosis was confirmed as hydatid cyst (Figure 4). No pathological findings consistent with hydatid cyst were detected in the liver or other systems. In the postoperative period, there was no discharge, infection or wound problems. Treatment of albendazole of $15 \mathrm{mg} / \mathrm{kg} /$ day was initiated and was continued for three months.
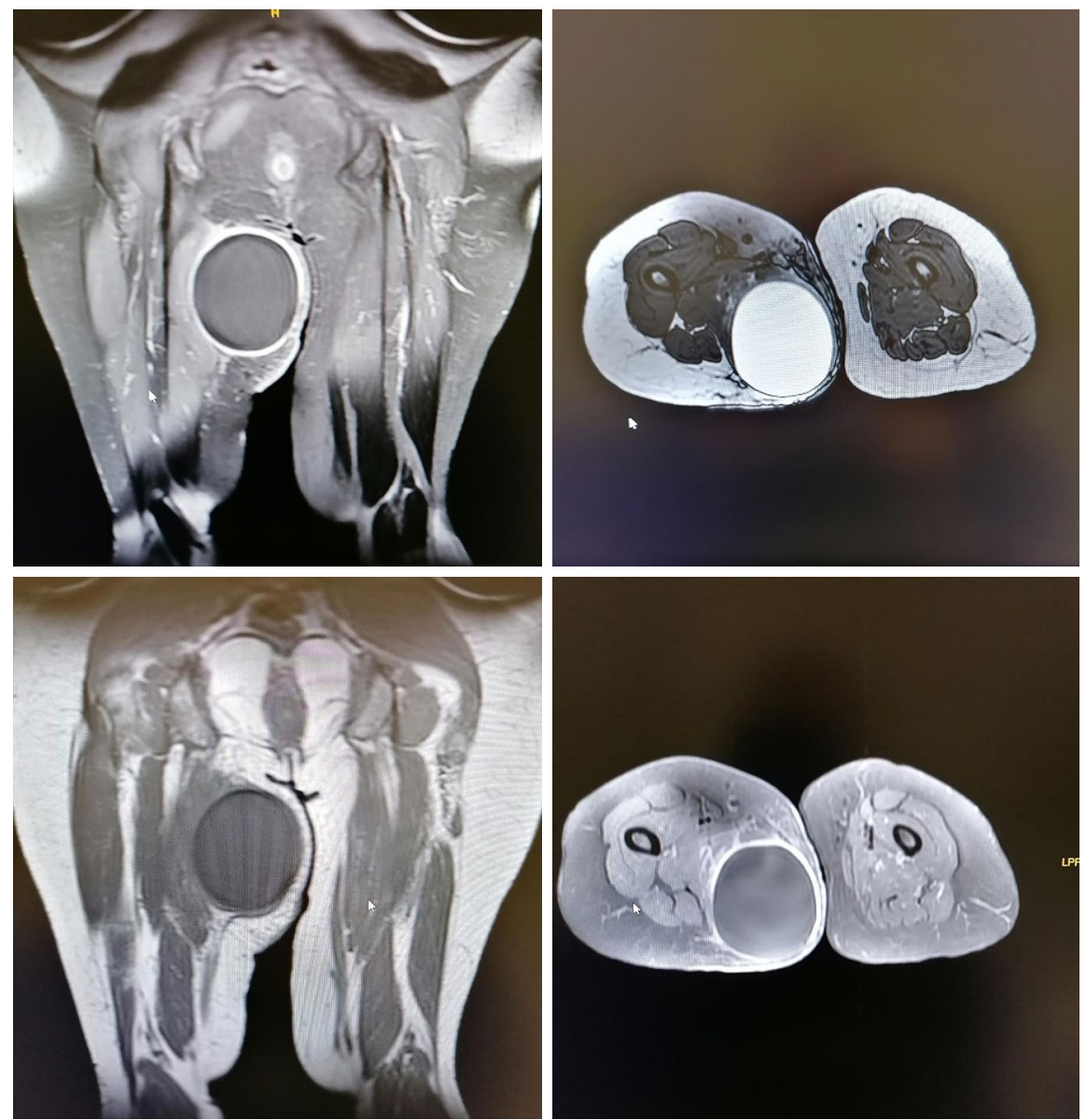

Figure 2. Magnetic resonance imaging of the patient. 

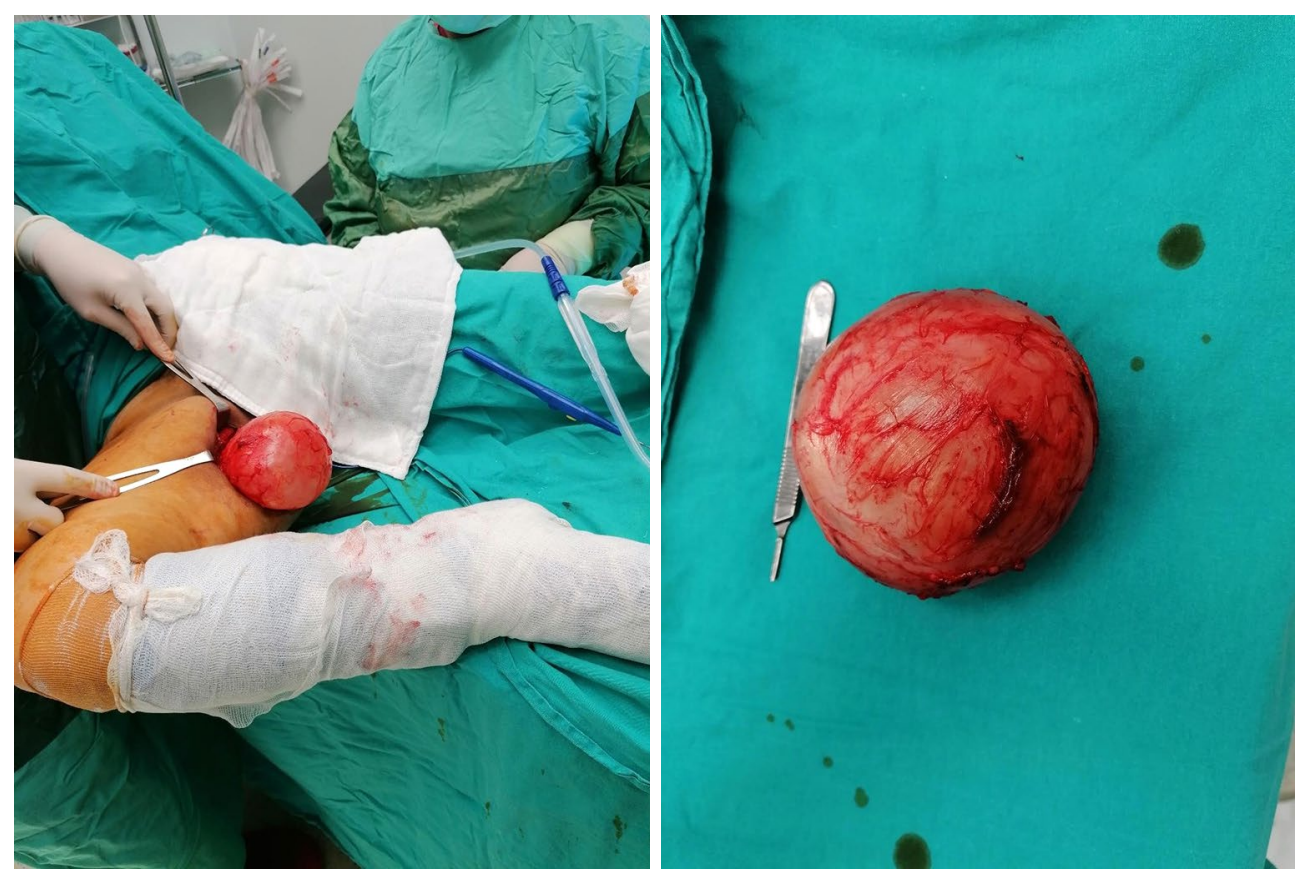

Figure 3. Intraoperative images of the cyst, $9 \times 10 \times 10 \mathrm{~cm}$ in size.

In the pathological evaluation, cystic tissue measuring $11 \times 11 \times 6 \mathrm{~cm}$ macroscopically was reported and was consequently reported as hydatid cyst.

The patient was informed that data from the case would be submitted for publication and gave her consent.

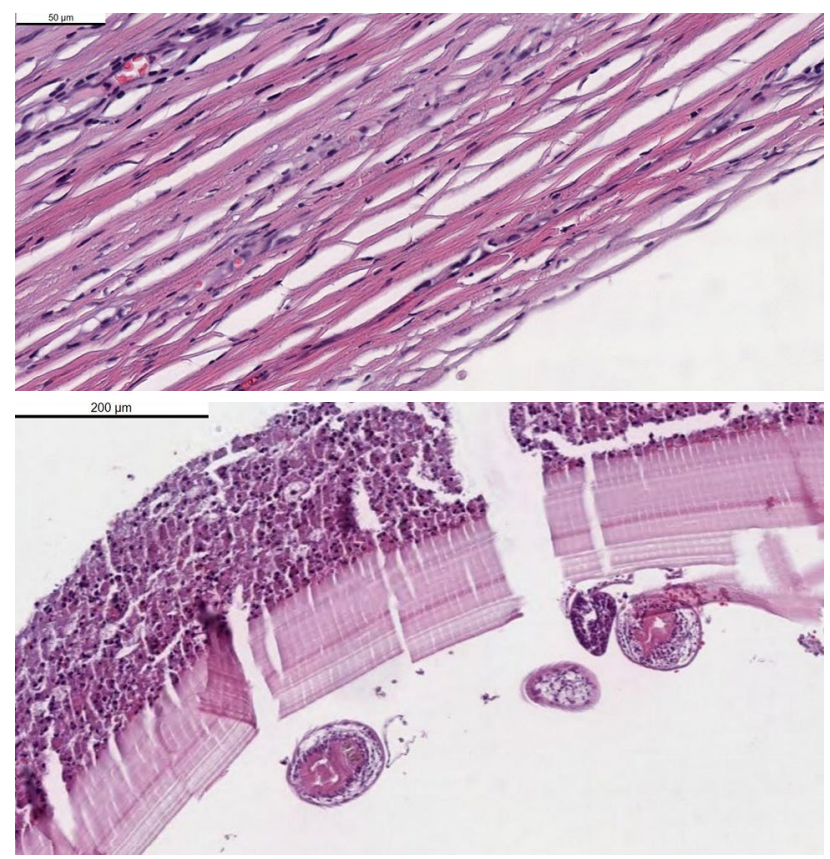

Figure 4. Microscopic appearance of the hydatid cyst.

\section{DISCUSSION}

Hydatid cyst in humans originates from the larvae of Echinococcus spp. parasites. The most widely seen form is E. granulosus, which has definitive hosts of carnivorous animals such as dogs, wolves, and foxes. Hydatid cyst disease of the liver and lungs caused by E. granulosus parasites is a significant health problem in countries where small and large animal farming is intense. Involvement of the musculoskeletal system has been reported at 1 to $4 \% \cdot{ }^{[3]}$ It is thought that muscle involvement is less common due to the filtration of the circulating larvae in the liver and lungs, as well as the lactic acid contained in the muscles. ${ }^{[4]}$

Khanna et $a l .{ }^{[5]}$ reported that, of 110 patients with hydatid cyst in a 10-year period, the disease was seen in 24 patients in atypical areas. Of these, the most frequent involvement was seen in the spleen, followed by the skin and soft tissue. Mseddi et al. ${ }^{[6]}$ reported that, for 11 cases of intramuscular hydatid cyst over a 17-year period, the most common localization was the thigh $(n=7)$, while the other localizations were paravertebral muscle, gluteal region, and anteromedial arm. In our case, the localization was the thigh muscles. Ates and Karakaplan ${ }^{[7]}$ reported that, in cases of intramuscular hydatid cyst, the cyst had mostly spontaneously spread from another region or developed secondary to surgical intervention for hydatidosis disease. In the postoperative tests in our case, no findings of 
hydatid cyst disease in any other region of the body were observed.

Intramuscular hydatid disease is often asymptomatic. A painless, slow-growing mass with overlying normal skin is the most frequently reported complaint in the literature. ${ }^{[8]}$ As hydatid cyst in muscle tissue is usually seen in the form of a soft tissue mass, it was difficult to diagnose this uncommon case preoperatively. There are some serological tests which are of benefit in diagnosis of Echinococcus spp., but serological tests may be negative in many cases. ${ }^{[9]}$ In the current case, the hydatid cyst indirect hemagglutination test was negative.

As a result of careless application or insufficient importance given to hydatid cyst surgery, the cyst can burst, leading to complications which can be severe such as the formation of secondary cysts through spreading or allergic reactions. ${ }^{[10]}$

A border structure is a typical finding of muscle hydatidosis. In the current case, as the mass did not have a multilocular appearance on MRI, it was reported as a simple cyst by the Radiology Department and no other diagnosis was considered preoperatively.

In hydatid cyst with muscle involvement, it should be considered that there may also be involvement of other organs, particularly liver and lung. Scanning of the current case was applied with abdominal ultrasound and pulmonary tomography, and there was no involvement of the lungs or liver.

Intramuscular hydatid cysts can mimic abscess, hematoma, lymphatic malformation, synovial cyst, and malignant soft tissue tumors. ${ }^{[9]}$ Preoperative diagnosis with clinical examination is of utmost important in hydatid cyst for differentiation from other soft tissue tumors. Biopsy is recommended in the diagnosis of soft tissue masses, but a biopsy performed on what is thought to be a soft tissue mass can lead to spread, causing live scolexes within the cyst to enter the circulation and anaphylactic reaction, or other compartments can be infected. ${ }^{[10]}$ Therefore, biopsy is contraindicated in hydatid cyst. ${ }^{[10]}$

In conclusion, particularly in areas of endemic hydatid disease, it must be kept in mind that these types of atypical localization, other than in the liver and lungs, can be encountered in many different anatomic regions. Laboratory and imaging methods may not always reach a definitive diagnosis. Therefore, the possibility of hydatid cyst must be considered before surgery and the cyst must be completely excised without piercing the cyst wall to avoid complications such as recurrence and anaphylaxis.

\section{Declaration of conflicting interests}

The authors declared no conflicts of interest with respect to the authorship and/or publication of this article.

\section{Funding}

The authors received no financial support for the research and/or authorship of this article.

\section{REFERENCES}

1. Kayaalp C. Hydatid cyst of the liver. In: Blumgart LH, Belghiti RJ, DeMatteo RP, Chapman WC, Büchler MW, Hann LE, et al, editors. Surgery of liver biliary tract and pancreas. 4th ed. Philadelphia: Saunders Elsevier, 2007. p. $952-70$.

2. Di Gesù G, Picone A, La Bianca A, Massaro M, Vetri G. Muscular and subcutaneous hydatidosis. Minerva Med 1987;78:835-40.

3. Tatari H, Baran O, Sanlidağ T, Göre O, Ak D, Manisali M, et al. Primary intramuscular hydatidosis of supraspinatus muscle. Arch Orthop Trauma Surg 2001;121:93-4.

4. García-Alvarez F, Torcal J, Salinas JC, Navarro A, GarcíaAlvarez I, Navarro-Zorraquino M, et al. Musculoskeletal hydatid disease: A report of 13 cases. Acta Orthop Scand 2002;73:227-31.

5. Khanna AK, Prasanna GV, Khanna R, Khanna A. Unusual sites of hydatid cysts in India. Trop Doct 2005;35:233-5.

6. Mseddi M, Mtaoumi M, Dahmene J, Ben Hamida R, Siala A, Moula T, et al. Hydatid cysts in muscles: Eleven cases. Rev Chir Orthop Reparatrice Appar Mot 2005;91:267-71. French.

7. Ates M, Karakaplan M. Hydatid cyst in the biceps and gluteus muscles: Case report. Surg Infect (Larchmt) 2007;8:475-8.

8. Tekin R, Avci A, Tekin RC, Gem M, Cevik R. Hydatid cysts in muscles: Clinical manifestations, diagnosis, and management of this atypical presentation. Rev Soc Bras Med Trop 2015;48:594-8.

9. Adryeke L, Cakır T, Duymus TM, Aydogmus S. Unexpected diagnosis in gluteal region -a primary intramuscular hydatid cyst: A case report. J Orthop Case Rep 2018;8:104-6.

10. Duncan GJ, Tooke SM. Echinococcus infestation of the biceps brachii. A case report. Clin Orthop Relat Res 1990;(261):247-50. 